\title{
Isolation and Characterization of Nitrogen Fixing Rhizobia from Cultivated and Uncultivated Soils of Northern Tanzania
}

\author{
Zephania Simon, Kelvin Mtei, Amare Gessesse, Patrick A. Ndakidemi* \\ School of Life Sciences and Bioengineering, The Nelson Mandela African Institution of Science and Technology, \\ Arusha, Tanzania \\ Email: ${ }^{*}$ ndakidemipa@gmail.com
}

Received 20 September 2014; revised 20 October 2014; accepted 20 November 2014

Copyright @ 2014 by authors and Scientific Research Publishing Inc.

This work is licensed under the Creative Commons Attribution International License (CC BY).

http://creativecommons.org/licenses/by/4.0/

(c) (i) 0 Exen Access

\section{Abstract}

Soil bacteria ${ }^{1}$ called rhizobia are gram-negative capable to colonize the soil immediately surrounding roots under the influence of the plant "rhizosphere" and reduce atmospheric nitrogen into the form available to plants through nitrogen fixation process. Nitrogen is the most limiting and supplied nutrient to most plants, and the determinant of plant growth. Legumes differ with most plants because they have access to nitrogen from both mineral and symbiotic sources. Small-scale farmers who are the major legume producers in Africa rarely apply fertilizers during legume production. Hence, the crop is largely dependent on fixed nitrogen from native nitrogen fixers. Isolation of rhizobia for legume production has been given a little attention in Africa due to inadequate research or negligence of researchers and unawareness of its potential in legume production as well as lack of an intention from skilled personnel to popularize the technology. Evaluation of effectiveness of isolated rhizobia is essential for inoculants preparation, host specificity recommendation and symbiotic effectiveness. The isolation, determination of their population in the soil and assessing factors affecting their population and testing the effectiveness of native nitrogen fixers with respect to right trap host crop are given a special attention in this review.

\section{Keywords}

Isolation, Rhizobia, Nitrogen Fixation, Symbiosis, Nodules, Legume, Most Probable Number

\footnotetext{
${ }^{1}$ Soil bacteria are called rhizobia and can be obtained from the soil by using distinct procedures. Their population in the soil depends on the land use system and the availability of host legumes among others. Trap legume crops can be used to obtain the specific rhizobia for symbiosis. *Corresponding author.
} 


\section{Introduction}

Nitrogen is the most limiting nutrient for growth of leguminous plants like Common beans, Soya beans, Cow peas and Garden peas because that present in the soil cannot support growth [1]. Nitrogen is essential in plant cells for synthesis of enzymes, proteins, chlorophyll, DNA and RNA, thus essential for plant growth and production of food and feed [2].

Nitrogen $(\mathrm{N})$ is a constituent of proteins, enzymes, chlorophyll, and growth regulators to plants and its deficiency causes reduced growth, leaf yellowing, reduced branching and small trifoliate leaves in legumes [3]-[5]. Despite the dramatically increase in the amount of synthetic nitrogen (N) applied to crops in the last 40 years from $12 \mathrm{Tg} /$ year to current $104 \mathrm{Tg} /$ year [6] there has been a significant decrease in yield with considerable persistence of vicious circle of poverty to majority farmers [7] [8].

Soil microorganisms specifically bacteria called rhizobia are able to colonise the rhizosphere, infect legume roots and biologically fix nitrogen in the soil through symbiotic process [9] [10] Biological Nitrogen fixation is a process of converting elemental nitrogen into the form of ammonia $\left(\mathrm{NH}_{4}^{+}\right)$and nitrate $\left(\mathrm{NO}_{3}^{-}\right)$available to plants [11]. Rhizobia can live on plant residues (saprophytes) or entirely within plants (endophytes) or (rhizobacteria) or in close association with the plant roots [9] [12]. Based on ability to fix nitrogen, rhizobia are classified into slow (Bradyrhizobium) and fast growing Rhizobia [13].The growth of Rhizobium visible in Yeast Extract Mannitol Agar (YEMA) is 3 - 5 days while Bradyrhizobium takes 6 - 8 days [14] [15]. The process in which the rhizobia colonize the rhizosphere, infect the roots and fix nitrogen leads to plant development and grain yield improvement [2] [16]. The effectiveness of rhizobial populations in fixing nitrogen is correlated with soil fertility status where acidic soils have been reported to contain less effective rhizobia strains [17].

Legumes are one of the most diverse plants on earth widespread in tropics and temperate zones [18]. They belong to one of superfamily of angiosperms (Leguminosae/Fabaceae) the order Fabales, in eurosid clade [19][21]. Legumes can grow in much degraded soils because they have the ability to fix nitrogen in association with rhizobia [22] [23]. Besides its major role in the traditional diets throughout the world, legumes provide a multiple benefits to both soil and other crops through intercropping [24]-[27]. Despite vast and potential uses of grain legumes like soybean, cowpea, common bean and peas as human food, animal feed and soil fertility enhancer, they can be grown in different agro-ecological zones [28]. Small-scale farmers who are the major legume producers in Africa rarely apply fertilizers during legume production due to their low income; hence the crop is largely dependent on fixed nitrogen from native nitrogen fixers [29]. In most cases, native nitrogen fixers are competitive to inoculants but not efficient strain and possibly incompatible to the host plant [30]. Therefore, relying on native nitrogen fixers without prior information on its efficiency and compatibility with host legume leads to crop production failure. The interaction between plants and soil microorganisms occurs much in the rhizosphere [31].

The legume-rhizobial symbiosis has a large impact on success of legumes hence the atmospheric nitrogen the organisms fix can be more than the fertilizer nitrogen an average farmer can afford to buy and apply [32]. Therefore, legume-rhizobia symbiosis can provide easy and inexpensive way to enhance soil fertility and improve crop production [33]. The root nodule rhizobia approximately reduce 20 million tons of atmospheric nitrogen to ammonia which is $50 \%-70 \%$ of the world biological nitrogen fixation [34]. The higher fixed nitrogen in hosts determines the success of symbiotic relationship between legumes and rhizobia [35]. However, host range expansion may be limited by the symbiont distribution while hosts can potentially acquire different rhizobia when invading new habitats [36].

Tanzania is among the countries endowed with mega-biodiversity of several biosphere reserves, world heritage sites and protected areas which constitute 35.6 percent of the territory [37] [38] Isolation and testing effectiveness of nitrogen fixing rhizobia from mega-biodiversity of Tanzania creates a platform for rhizobia inoculant production for improving crop production through legume-cereal intercropping.

\section{Isolation of Nitrogen Fixing Rhizobium/Bradyrhizobium from Soils}

Rhizobia are very important for crop production because they form symbiotic relationship with legume the process that converts atmospheric elemental Nitrogen $\left(\mathrm{N}_{2}\right)$ into ammonia $\left(\mathrm{NH}_{3}\right)$ accounting for $65 \%$ of the nitrogen currently utilized in agriculture [2]. The isolation and characterization of rhizobia is a valuable biological resource for finding bacterial strains with effective rhizobium-legume association to maximize the agricultural production [39] [40]. Rhizobia are phenotypically and numerically diverse of which many remain unidentified [41] 
In a study for characterization of indigenous rhizobia nodulating chickpea in India, 53 rhizobial strains were isolated and 28 selected for diversity analysis [42]. Zahran et al. [43] isolated 68 rhizobia species in Egypt which were reported to be good candidates for establishing symbiosis in various Egyptian environments. During the study for isolation and characterization of Rhizobium specie and determination of their potency for growth factor production, 260 bacteria were isolated on plate count Agar up on which 53 were nitrogen fixing rhizobia and 43 types of morphologies were found with 5 effective rhizobia strains producing plant growth factors [44]. The study for isolation and biochemical characterization of rhizobium meliloti from root nodules of alfalfa (medico sativa) revealed twenty five 25/50 samples of root nodule with presence of Sinorhizobia meliloti [45]. The continuous isolation and characterization of new strains from diverse environment is of paramount importance.

There are about 19,700 legume species currently known to grow around the world with few respective microsymbionts studied [39] [40]. However, the wide forest reserves in Tanzania with varying characteristics is the noble platform for isolation of effective rhizobia strains for nitrogen fixation. Farmers in northern Tanzania mostly intercrop cereal with common beans (Phaseolus vulgaris), Cow pea (Vigna unguiculata) and Garden pea (Pisum sativum) [46]. Most farmers in Tanzania are not aware about the use of native rhizobia inoculants as biofertilizers because the knowledge is not the first priority in agricultural production and even the rhizobia inoculants are not readily available. Therefore, isolation of efficient native nitrogen fixing rhizobia for common beans (Phaseolus vulgaris), Soybean (Glycine max), Cow pea (Vigna unguiculata) and Garden pea (Pisum sativum) and produce them as inoculants to improve legume production is important.

\subsection{Legume-Rhizobia Symbiosis}

Legumes are believed to have emerged since 59 - 60 Million years ago (Ma) early in the Tertiary period and its subfamilies to have evolved between 56 - $50 \mathrm{Ma}$ [18] [47] and can survive even in poor soils where there is not enough nitrogen to support other types of plants [23]. However, rhizobia are thought to be present before the legumes for nodulation because Sino rhizobium-Bradyrhizobium split was reported about 500 Ma [48] [49]. Bacteria of the genus Bradyrhizobium, Rhizobium Sinorhizobium and others induce nitrogen-fixing nodules on the roots of legumes such as peas, beans, cow peas and soybeans [50].

The process of symbiosis is such that rhizobia supply a constant source of reduced nitrogen to the host plant in exchange of nutrients and energy for its activities [51] because plants cannot directly utilize nitrogen stored in the soil as organic matter except in $\mathrm{NH}_{4}^{+}-\mathrm{N}$ and $\mathrm{NO}_{3}^{-}-\mathrm{N}$ inorganic forms [52]-[54]. The interaction between root nodules and their symbiotic bacteria has been studied through proteins (proteomics) produced by both partners during their signal exchange and growth of symbiosome. The study has identified hundreds of proteins with development and functioning of rhizobial symbiosis [55]-[57]. The pathogen-responsive proteins induced by a variety of biotic and abiotic stimuli protect plants against pathogenic fungi, bacteria, viruses and adverse environmental conditions [58].

When nitrogen in the soil is inadequate, legumes release flavonoids which signal to rhizobia that the plant is seeking symbiotic bacteria [59] [60]. In response, the rhizobia releases nodulation factor which stimulates the plant to create deformed root hairs [61]. Rhizobia then form an infection thread for allowing them to enter the root cells through root hairs [62].

When the rhizobia are inside the root cells, the cells divide rapidly to form nodule [63]. Then the rhizobia convert atmospheric nitrogen into ammonia, a form that is directly used by the plant for synthesis of amino acids and nucleotides, the plant provides the bacteria with sugars, hence the symbiosis is established [64]. Biological nitrogen fixation has gained attention in recent years because it substitutes inorganic fertilizer and is environmental friendly farm inputs essential for poor resource farmers [65]. It also limits groundwater's pollution by nitrates [40]. There are two major groups of bacteria fixing nitrogen within nodules of vascular plants; rhizobia (Alpha-proteobacteria) associating with legumes and Frankia (in actinobacteria). These are filamentous slow growth rate bacterium forming hyphae colonies without an aerial mycelium and have vesicles and spores, the unique differentiated developmental structures critical to its survival [66].

Grain legume like soybean, cowpea, common bean and peas are used in a wide range of products and are important crops for sustainable agriculture [67]. More studies on interaction between rhizobia and legume are essential in unexploited area. Therefore isolation of native nitrogen fixing rhizobia from the soils obtained from farmers' fields and from virgin land through the use of legume trap host crop provides a perfect match between legume and rhizobia for efficient nitrogen fixation leading to improve legume production. 


\subsection{Host Specificity and Symbiotic Effectiveness}

Host specificity refers to the ability of particular rhizobia species to form nodules on specific legumes [68]. The approach of using effective or superior exotic rhizobia strains as inoculants has failed in various environments due to various reasons including the use of ineffective and non-competitive rhizobia strains as inoculants [69] [70]. The host specificity leads to a perfect match between legume and rhizobia resulting into effective nodules (deep red inside) formation and nitrogen fixation [71]. If cross inoculation with no perfect match has occurred, ineffective nodules (green or white inside) or no nodules may be formed and nitrogen fixation does not occur [72].

The host specificity and symbiotic interaction is conferred by the particular root exudates (flavonoids) and the Nod factor structure composition [65]. It is enhanced by bacterial recognition of the flavonoids produced by a host species providing opportunity for plant choice as the only correct flavonoid for induction of symbiotic gene expression in a particular rhizobium strain [73]. The particular flavonoid signal perceived by bacteria is mediated in part by the transcriptional regulator NodD, varying functionally among rhizobial strains [74]. The lipo-chitin oligosaccharide (LCO) "nod factors," is then produced to influence the regulation of plant genes leading to recognition of specific legume host [73]. Bacterial nod factors are composed of four to five beta 1 - 4 linked $\mathrm{N}$-acetyl glucosamine units (a chitin backbone) and a fatty acid [58]. The nod factors differ in their fatty acids, lengths of their sugar backbones, saturation of the acyl unit and decorations (glycosylation, sulfation, and methylation) of the reducing and non-reducing ends of the backbone [75]-[77]. The nod factors produced by rhizobia are diverse, and plant discrimination of the same contributes the second level of specificity to the interaction and create an opportunity for plant partner choice [75]. The rhizobium cell walls are composed of varying polysaccharide which provides another opportunity for plant partners choice using the "lock and key" cascade that determines the degree of plant and bacterial specificity [75]. Some researchers have reported that rhizobia of different genera can infect the same plant species but some plant species can strictly be infected by rhizobia from only one specific genera [78] [79].

Cowpea has been reported to be nodulated by rhizobia isolated from soybean, ground nuts and Bambara ground nuts but these legumes cannot be nodulated by rhizobia isolated from cow pea [80]. This is an essential phenomenon when providing recommendation on efficient inoculants for legume production [81] [82] and developing efficient nitrogen fixing rhizobia inoculants because inoculants are introduced into new environments previously not been cultivated and which may lack compatible rhizobia strain [83]. Strain 042B for soybeans in China was reported to have high symbiotic efficiency than Bradyrhizobium japonicum and displayed early appearance of nodules with higher nitrogenase activity [84]. Therefore, identification of rhizobia strains in African farmers' fields using specific hosts and testing its efficiency in nitrogen fixation and effectiveness in cross inoculation is essential for improvement of legume production.

\subsection{Nitrogen Fixation and Crop Productivity}

Legumes growth and productivity is normally limited by fixed nitrogen in all environments with suitable climate and available water to support life [85]. Soil fertility can be enhanced through the concept of using, improving and restoring the symbiotic rhizobia [86]. The fact that rhizobia inoculants are inexpensive source of biofertilizers, is a means for sustainable legume supply to the growing population hence is environmental friendly [87]. Legume is considered the major nitrogen fixers [88]. When legumes are ploughed or cut back to the ground, the root nodules release all the valuable biological fixed nitrogen to the soil for the following crop [89].

The estimated contribution of prokaryotes to the nitrogen input of soil ranges from 0 to $60 \mathrm{Kg} / \mathrm{ha} / \mathrm{year}$ [90] or estimated to be about 175 million metric tons annually and about $70 \%$ of all annual fixed nitrogen on the earth; the rest is by micro-organisms, autotrophs or heterotrophs called "free fixers" [91]. Biological nitrogen fixation contributes about 100 million tons of nitrogen for terrestrial ecosystems, 30 to 300 million tons for marine ecosystems and 20 million tons from chemical fixation due to atmospheric phenomena [92]. There has been an increase in the use of nitrogenous chemical fertilizers for cereal and other agricultural crops production since the Second World War [93]. The increase has led to various consequences such as water pollution and eutrophication due to leaching of nitrogen in the soil by rain and irrigation [94]. In order to minimize the consequences, the use of nitrogen-fixing rhizobia can play an important role in the life of host plant because it ensures their nitrogen supply, defense against pathogens and pests as well as adaptation to various environmental stress [91].

Botha et al. [88] in South Africa reported that CB 1809 strain for soybeans was 60\% superior of the isolates 
tested in efficient nitrogen fixation from Bergville and Morgenzon and was similar to $73 \%$ of isolates from Koedoeskop. Sadowsky et al. [95] in USA reported that three phaseolus plant introduction out of 684 genotypes examined were found to form effective symbiotic nitrogen-fixation with the Rhizobium fredii strains and 9 nitrogen fixing efficient strains of Phaseolus vulgaris was observed to have between 5 to 10 nodules per plant. In Zimbabwe, smallholder farmers consider nitrogen fixing rhizobia inoculants as having magic properties due to high growth rate and dark green colour of the inoculated legume plants compared to uninoculated [96]. Farmers in Africa are legume producers despite the challenge of low essential macro and micronutrients in the soil. There are no adequate reports on relationship between nitrogen fixation and crop productivity records for different farming systems used in Africa.

The identification of native strains capable of fixing nitrogen will provide an inexpensive solution for enhancing legume production if properly utilized by the majority of small scale farmers in Africa.

\section{The Factors Affecting Rhizobia Population, Legume and Nitrogen Fixation}

Nitrogen fixing rhizobia cannot express their full potential in fixing nitrogen if the environment and the plant is in poor state [97] [98]. The process of nitrogen fixation depends much on the functional state of the legume plant [99] and the optimum environmental conditions supporting the macro and microsymbionts. The nitrogen fixing rhizobia vary in their tolerance to major environmental factors [100]. Environmental stresses can affect the host plant and symbiotic rhizobia [101]. The most threatening environments for rhizobia functions are marginal lands with low rainfall, acidic soils with poor water holding capacity, nutrient stress and temperature extremes [51]. The proposed critical levels of mineral requirement for effective legume growth for soils in Tanzania are as shown in Table 1.

\subsection{Temperature Extremes}

High temperatures have effects on the root nodule structure, function and root hair infection [100]. The best temperature for nodule functioning in common beans (Phaseolus vulgaris) is between $25^{\circ} \mathrm{C}-30^{\circ} \mathrm{C} \mathrm{[102]} \mathrm{[103].}$ The optimum temperature range for rhizobia has been reported to be $2^{\circ} \mathrm{C} 5$ to $31^{\circ} \mathrm{C}$ in culture media but rhizobia isolated from hot and dry Sahel Savannah environment were reported to grow well at $40^{\circ} \mathrm{C}$ [104]. The favorable recommended temperature for root hair development and large number of infection is between 15 and $20^{\circ} \mathrm{C}$. The limits of low temperature for crops native to temperate region is $2^{\circ} \mathrm{C}$ while for tropical species is $10^{\circ} \mathrm{C}$ [105]. Legume species can fix nitrogen at different critical levels of temperature such as $35^{\circ} \mathrm{C}-40^{\circ} \mathrm{C}$ for soybeans and cowpeas, and $30^{\circ} \mathrm{C}$ for peas [106].

The 68 rhizobia species isolated in Egypt grew at temperature ranging from $20^{\circ} \mathrm{C}-35^{\circ} \mathrm{C}$ though some species grew at $35^{\circ} \mathrm{C}-40^{\circ} \mathrm{C}$ and at maximum of $50^{\circ} \mathrm{C}$ [43] Successful isolation of high temperature tolerant rhizobia for common bean has been reported in various regions (107). The rhizobia population in relation to temperature for across different zones in Africa still needs more research. The low temperature experienced at the highlands and high temperature with low moisture content in lowlands has resulted into varied crop yield from one season to another. Therefore, isolation of native rhizobia species from extreme temperature range as those found in Africa is essential for obtaining temperature tolerant rhizobia species for improvements of legume yield.

\subsection{Drought (Soil Moisture Deficiency)}

Both rhizobia and legume can exist in soils with low moisture levels with the lowest population densities reported in most desiccated environments [51]. Drought reduces the rhizobia population in soils, inhibits nodulation and $\mathrm{N}_{2}$ fixation [107]. Nitrogen fixation process is highly sensitive to the deficiency of soil moisture [107]. Rhizobia population in relation to drought has received little attention in Tanzania and Africa at large. Most dry lowlands in Africa are characterized with low moisture content and high annual temperature range. Therefore, successful isolation of rhizobia from such environment will definitely result in obtaining good rhizobia candidates for establishing successful symbioses in drought environments useful for production of common bean and other legumes.

\subsection{Soil Acidity and Related Stress}

Soil acidity and related problems of manganese and aluminum toxicity as well as calcium deficiency seriously 
Table 1. Proposed critical levels of mineral requirement for soils in Tanzania.

\begin{tabular}{ccc}
\hline Mineral & Proposed critical levels & Reference \\
Nitrogen (N) & $2 \mathrm{~g} / \mathrm{Kg}$ soil & {$[113]$} \\
Phosphorus (P) & $10-15 \mathrm{mg} / \mathrm{Kg}$ of soil & {$[114]$} \\
& Exchangeable cations & {$[115]$} \\
Potassium (K) & $0.20 \mathrm{cmol} / \mathrm{Kg}$ of soil & {$[116]$} \\
Magnesium (Mg) & $2 \mathrm{cmol} / \mathrm{Kg}$ of soil & {$[117]$} \\
Calcium (Ca) & $5.0 \mathrm{cmol} / \mathrm{Kg}$ of soil & {$[116]$} \\
Aluminum (Al) & $1.0 \mathrm{cmol} / \mathrm{Kg}$ of soil & {$[113]$} \\
\hline
\end{tabular}

affect nodulation, $\mathrm{N}_{2}$ fixation and plant growth [108]. Nitrogen fixation by rhizobia to most leguminous plants is effective at neutral or slightly acidic soils [109] [110]. Researchers have reported that most legume species fail to nodulate at $\mathrm{pH}$ less than 5.0 because cannot withstand acidic condition [111]. A study conducted in Kenya revealed that common beans (Phaseolus vulgaris) can be nodulated by both rhizobia from low $\mathrm{pH}$ (acidic soils) and high pH soils [100] [110]. Rhizobia isolated in Egypt grew at pH ranging from 6 - 8 with some being able to tolerate acidic $\mathrm{pH}$ ranging from 3.5.to 4.0 and alkalinity at $\mathrm{pH}$ ranging from 9 - 10 [43]. Rhizobium tropici is a species adapted to acidic soils than any other species of Rhizobium reported to nodulate Phaseolus vulgaris [112]. Bother et al., [79] in South Africa reported that the Bradyrhizobia population serotype 135 for soybeans was observed to be adapted to alkaline soils at Koedoeskop while serotype 122 was adapted to soils of neutral or acid $\mathrm{pH}$ thus could not survive well in Koedoeskop soils. In China it was reported that strain 042B was adapted to alkaline soils with $\mathrm{pH} 10.7$ and a wider range of temperature from $10^{\circ} \mathrm{C}-42^{\circ} \mathrm{C}$ and can grow faster in unfavourable environments and utilized a wide range of carbohydrates than other strains nodulating soybeans providing an essential commercial value for industrial inoculum production [84].The relationship between rhizobia population and soil $\mathrm{pH}$ for Tanzania and Africa at large still needs more research due to soil characteristics varied with altitude and rhizobia diversity. Therefore; isolation of rhizobia from varied locations with wide range of soil $\mathrm{pH}$ is a pavement to acquire effective native rhizobia tolerant to low and high soil pH.

\subsection{Salt and Osmotic Stresses}

Researchers have reported the detrimental effect of salt on growth and survival of rhizobia [118] [119]. The response of legume to salinity varies much depending on soil properties, climatic conditions and plant growth stage [120] [121]. Salt and osmotic stress can affect the initial stage of legume-rhizobial interaction and nodule formation than it does to rhizobia [122]-[124]. The root hair formation on plants is more sensitive to salt than rhizobia cells hence rhizobia can tolerate salinity from 4.5 to $5.2 \mathrm{dsm}^{-1}$ [125] [126]. The Rhizobium leguminosarum for common beans (Phaseolus vulgaris) can tolerate up to $350 \mathrm{mM} \mathrm{NaCl}$ concentration in broth culture while those for Vigna Unguiculata can tolerate up to $450 \mathrm{mM} \mathrm{NaCl}$ concentration [104]. Some rhizobia species can tolerate moderate salinity soils and fix nitrogen effectively [127].

In order to establish a successful rhizobia-legume symbiosis for saline environments, efficient salt tolerant native rhizobia strains should be isolated from saline soils [118] [128]. The study conducted in Meru and Hai Districts northern Tanzania reported that Bradyrhizobia and rhizobia inoculants are efficient supplier of nitrogen to common beans and soy beans respectively and that inoculation is a better option to poor resource farmers who cannot afford to buy expensive inorganic fertilizers [119]. This process is environmental friendly source of nitrogen which is renewable and can replace or complement mineral fertilizer inputs [120] [121].

Therefore, isolation and estimation of the population density in relation to salt and osmotic stress for native rhizobia nodulating common beans, cowpeas, soybeans and peas across favorable to unfavorable rhizobia growth conditions across Africa is a means for improvement of legume production.

\section{Rhizobia Population Estimates Using the Most Probable Number (MPN)}

The most probable number (MPN) plant-infection is a technique for the enumeration of rhizobia in soils and in inoculants for legume inoculant testing program. The MPN technique relies upon the pattern of positive or nega- 
tive nodulation responses of host plants inoculated with consecutive series of dilutions of sample containing rhizobia [83]. The technique is applied under the following major assumptions: 1) a single viable rhizobium cell inoculated onto its specific host in a Nitrogen-free medium will cause nodule formation; 2) nodulation is the proof of infective Rhizobia; 3) the validity of the test is demonstrated by the absence of nodules on uninoculated plants; and 4) absence of nodules on inoculated plants is proof of the absence of infective rhizobia. The MPN of rhizobia in hot and dry region and in the region receiving heavy rainfall has been reported to be low while in the region receiving moderate rainfall, the population is high [126] [128]. Cultivation of legume in an area has been reported to influence the population of rhizobia.

The study conducted in Iowa fields grown with Soybean within the previous 13 years reported the MPN of Bradyrhizobium japonicum to be correlated with whether soybeans had or not been grown at the site within the previous 13 years [124] [125].

The study conducted in India at the field grown legume for at least 15 years ago showed no yield response to inoculation because native nitrogen fixing rhizobia for nodulating cowpeas and common beans were still present in the soil with the population ranging from $6 \times 10^{0}$ to $1 \times 10^{4}$ per gram of soil but Rhizobium japonicum for soybeans were not found in any of the soil samples [51]. The study conducted in Tunisia using MPN reported the increased number of nodules and shoot dry yield to more than twofold when $R$. gallicum strain 8a3 were inoculated to common beans and the nodule count was observed to be higher even from the soil with population of $10^{6}$ native rhizobia $g^{-1}$ soil [129]. In South-West Spain, the study conducted using MPN count reported that rhizobia population ranged between $3.6 \pm 42.4$ rhizobia per gram of soil in uncropped soil and about $4 \times 10^{3}$ rhizobia per gram of soil in cropped soil.

However, most isolated strains were more efficient in nodulating common bean than the control and there were no association between soil properties and presence of common bean nodulating rhizobia [130]. In Brazil using MPN technique, [131] reported that rhizobia population nodulating common bean ranged between $7.6 \times$ $10^{4}$ and $1.57 \times 10^{3}$ cells per gram of soil in the plot with $4 \%$ aluminum saturation and unlimed plot respectively. In Nigeria using MPN, Aliyu et al. [132] found that native rhizobia population estimates for soybeans were very low in slightly acidic soil and were not found in moderately acidic soils. However, the rhizobia for nodulating cowpea were relatively high in slightly acidic soils and significantly high in moderately acidic soils. The rhizobia estimates using MPN in soils from Embu district in Kenya varied with the system of land use; the population range for land use under coffee, tea, maize-beans intercrop and fallow was between $1.1-2.3 \times 10^{2}$ cells per gram of soil while $6.1 \times 10$ and 0 cells per gram of soil were recorded for land use under Napier and natural forests respectively [133] [134]. In Poland using MPN technique, $R$. leguminosarum bv. Phaseoli population for common bean was observed in 21/32 soils ranged between $\log 2.23$ - 5.34 [135]. The study conducted in Japan by [136] revealed that the native rhizobia population isolated from cultivated soil nodulated to Yezin-3 (Rj4) and Yezin-6 (non-Rj) were $1.16 \times 10^{4}$ and $1.16 \times 10^{5}$ cells per gram of soil respectively. The population was associated with the content of nitrogen and silt-clay fractions in the soil indicating that it was affected by the absence of plant host [136] [137].

Dudeja and Ghurana [138] in India reported that inoculated Bradyrhizobia population varied with time in different soil layers from $10^{1}-10^{2}$ in July to $10^{2}-10^{3}$ in August to September and 47 rhizobia per gram of soil in October. However, he increase in soil moisture content led to increase in rhizobia population to $10^{3}$ per gram of soil constantly soon after the onset of rainfall. The study conducted in Isinya District Kenya using MPN reported that rhizobia collections were found in varying densities in all the sampled plots and the natural grasslands had low rhizobia concentration (575 cells/g soil), the population declined with repeated cultivation of non-legume crops but increased sharply (30,000 cells/g soil) with the introduction of grain legumes [139]. Maingi [137] in Kiboko at Makueni District, Southeast Kenya (semi-arid to arid conditions) using MPN count reported that the total Bradyrhizobia population was between $2.59 \times 10^{4}$ and $1.89 \times 10^{5}$ per gram of soil. The population size of taxonomically defined slow growing Bradyrhizobia in Kiboko was between $2.59 \times 10^{2}$ and $1.89 \times 10^{3}$ cells per gram of soil sample while the approximate Bradyrhizobia population specific to TGx genotype was between $7.81 \times 10^{2}$ and $5.67 \times 10^{3}$ cells per gram of soil [140].

In Kaguru at Meru District, East Kenya (semi-humid climate) the approximate total Bradyrhizobia population was between $1.04 \times 10^{2}$ and $7.56 \times 10^{3}$ cells per gram of soil. The population size of taxonomically defined slow-growing Bradyrhizobia was between $1.33 \times 10^{2}$ and $9.72 \times 10^{2}$ cells per gram of soil while the approximate Bradyrhizobia population specific to TGx genotype was between $2.37 \times 10^{2}$ and $1.73 \times 10^{3}$ per gram of soil [140]. The rhizobia abundance and nitrogen depletion was reported to be led by vegetation clearing and cul- 
tivation of cereal crops without intercropping with legume [139]. Regular crop rotation with grain legumes can replenish soil fertility through biological nitrogen fixation and significantly improve crop yields and food security. The repeated cultivation of symbiotic legumes can lead to rapid increase of rhizobia population and significant improvement of soil Nitrogen fixation [139].

Due to the fact that inoculant price is low compared to the potential benefits they provide, farmers should be encouraged to inoculate each season of the production year [141]. Rhizobia population has been reported to be high in legume cultivated areas and in wild vegetation whether leguminous or not [51]. It is therefore essential to conduct the research for MPN of native rhizobia in both uncultivated (wild) and cultivated regions in Africa to establish the critical levels and create the platform for rhizobia inoculation in soils with varied characteristic.

\section{Estimation and Characterization of Rhizobia Population Using Serological Techniques}

Serological techniques has been used in the study of rhizobia for strain identification, ecological investigation of serological relatedness of strains and their antigenic composition [142] The techniques has also been used to identify some organisms depending on their cells immune response to foreign organism that enters their body [143]. The technique applies agglutination, immuno-diffusion and immuno-fluorescence techniques in investigation of rhizobia cells [144]. Most studies report indicates that rhizobia are serologically heterogeneous group of organisms [145] Different strains isolated from the same host could serologically be unrelated [146]. The strains isolated from different nodules on the same plant could serologically be unrelated [147]

Agglutination reaction has been used to assess the serological relatedness of strains and species of rhizobia [148]. The studies conducted in Hawaii to examine serological relatedness of 25 strains of slow-growing Rhizobia japonicum by agglutination identified 6 somatic serogroups [143] [149] Raposeiras, and Marriel [150] in Brazil reported that SLA 2.2 native rhizobia strain and CIAT 899 commercial strains are competitive strain for bean inoculation in soils with low fertility and reduced rhizobia population. Gao and Yang [48] in China reported that strain 042B could form nodules and fix nitrogen to both alfalfa and soybeans with nodule occupancy ranging from 82\% - 90\% while that of strain USDA110 ranged from 78\% - 46\%. Bizarro and Giongo [151] in Brazil reported that 27/75 isolates from soybeans were similar to original strain with strong correlation obtained in their genetic variability.

Immuno-diffusion is another technique used extensively to investigate the serological relationships between various strains and species of Rhizobium [152]. It has the resolving power in distinguishing between antigenically identical and closely related but not identical strains [153]. The studies for immunodiffusion of 62 fast growing strains of lotus rhizobia indicated that while fast and slow growers shared no common somatic antigen, internal antigen were shared by fast growing strains [143].

Fluorescent Antibody (FA) is among the most used technique for direct examination and identification of rhizobia strains in the culture media, nodules and direct enumeration of specific strains from the soil [154] .The technique is essential because needs only small amount of antigen and antibody and is the only technique capable for the study of rhizobia insitu [155]. Enzyme-linked Immunosorbent Assay (ELISA) is another technique mostly used for identification of bacteria in the soil or in plants. It uses antibodies and colour change to identify a substance. Moawad et al., [156] in Egypt assessed the competition for nodulation using FA technique and reported that Phaseolus 163 inoculant strain occupied 30\% - 40\% in both soils and 38\% - 50\% of nodules on Bronco cultivar and at least $50 \%$ of the nodules on the Bronco were occupied by native rhizobia. Serological techniques in characterization of native rhizobia effectiveness in fixing nitrogen from the mega-biodiversity in Africa are essential for legume production.

\section{Evaluation of the Nitrogen Fixing Capability of Isolated Strains and Their Effects on Legume Production}

The symbiotic Rhizobia-legume system is the major contributor of biologically fixed nitrogen as compared with non-symbiotic nitrogen-fixing bacteria [157]. The system is estimated to contribute $1.44 \times 10^{8}$ metric tons of nitrogen per year globally [158]. The application of nitrogen fertilizers in Kenya was reported to increase the dry matter and grain yield in common beans (Phaseolus vulgaris) but led to decreased number of nodules per plant.

Rhizobial inoculants application increased both the nodule number and dry weight although the effect was not realized on plant growth and grain yield and the application of farm yard manure only increased the number of 
nodules during short rain season [159]. The study conducted in Egypt for assessing the performance of phaseolus bean rhizobia in the Nile Delta soils reported a positive response to inoculation of Giza 6 in terms of nodule numbers, dry matter and plants biomass accumulation and CE3 strain enhanced plant growth and high nitrogen uptake compared with Phaseolus 163 strain [160]. Mehrpouyan [161] reported that in Zanjan province the nodule number and weight was increased in inoculated treatments and the nitrogen fixation was higher while the average yield increased about $43 \%$ compared with the non-inoculated (control).

In Khuzestan province the yield of inoculated common beans was 35\% to $69 \%$ higher than controls while the grain yield for inoculated soybeans increased twice compared with the maximum fertilizer treatments and 10 folds relative to the control. The percentage of grain protein content was reported to be higher in inoculated treatments than the control. In Iowa, Bradyrhizobium japonicum was reported to have different competitive ability on soybeans nodule formation. The isolated native rhizobia strains were effective in nitrogen fixation on common beans because they were able to compete with the exotic rhizobia species. Gicharu and Gitonga [162] reported that Greenhouse inoculation of multi-strain on climbing common bean (Phaseolus vulgaris) in Kenya produced the highest number of nodules and yield than the control but in the field, the highest dry weight was produced by USDA 2676 inoculant. This means that the native rhizobia in the control were competitive and effective in fixing nitrogen to meet the host nitrogen requirements level thus there were no need to use new inoculants at such field [163]. The study conducted by Maingi [164] in Kenya revealed that most isolates were rhizobia with different morphology, the isolated strain 446 was more effective in fixing nitrogen compared with Rhizobium leguminosarum biovar phaseoli and the nodulated legume plants had the highest shoot dry weight than the non nodulated plants. All rhizobia strains isolated from Amazon soils during the study for evaluating plant growth-promoting traits of Rhizobium strains for their co-inoculation in common beans (Phaseolus vulgaris) were found to fix nitrogen efficiently as free living bacteria [165].Weaver and Frederick [166] reported that there were no increase in yield even when there were less than $1.1 \times 10^{1}$ native rhizobia per $\mathrm{g}$ of soil regardless of majority nodules being formed by inoculum strain. Also inoculation to common beans formed no nodules when the number of native rhizobia was $1 \times 10^{2}$ per $g$ of soil but the nodule number was increased when the number of rhizobia was below $6 \times 10^{0}$ per g of soil and the yield of soybeans increased by $62 \%$.

The number of native rhizobia was inversely related to the inoculant rhizobia in terms of inoculation and the successful competition. One of the reason for the failure to achieve successful inoculation with efficient rhizobia is the stiff competition for nodule sites posed by native rhizobia [167]. Abaidoo and Van Kassel [168] reported a higher accumulated shoot dry matter in inoculated soybeans intercropped treatments than in monocroping systems with inoculated and non-inoculated treatments. Furthermore, common beans dry matter accumulation was higher in uninoculated than inoculated treatments; The results suggests that there were high competition for nutrients in common beans than in soybeans intercropping systems from native rhizobia species. However, higher nodulation and nitrogen fixation was found in common beans intercropped with maize planted in the same hole than otherwise, possibly due to nitrogen stress caused by maize utilizing the fixed nitrogen. Conversely, Allen and Obura [169] reported the increase in dry matter and nitrogen when maize was intercropped with cowpea and decrease from $23 \%$ - 26\% when maize was intercropped with inoculated soybean. These results suggest that a benefit to non-legume crop on fixed nitrogen will depend on efficiency of legume in fixing nitrogen. Inoculated plants have been reported to develop vigorously with high shoot dry matter contents from effective symbiosis of about 84\% [170]. Most researchers have reported the increased number of pods, yield, and seed number per pod, dry weight of pods per square meter, biomass, Leaf Area Index and 100 seed weight in inoculated than non-inoculated treatments with no significant difference for grain harvest index [171] [172]. Nitrogen fixation is reported to be affected by the nature of the rhizobia population such that low rhizobia population may not nodulate the host adequately and the ineffective population may fail to nodulate the host to its nitrogen requirements [173].

Nitrogen fixing rhizobia have been reported to vary in their ability to compete, infect and fix nitrogen in their hosts due various factors such as host symbiont compatibility, soil salinity, soil $\mathrm{pH}$, mineral and heavy metal toxicity, temperature extremes, inadequate or extreme soil moisture and nutrient deficit [174]. The only alternative to acquire successful inoculation is by using effective native rhizobia strains. Therefore evaluation of the capability of isolated native nitrogen fixing rhizobia for legume provides a way forward for yield improvement.

\section{Conclusion}

Isolation and testing effectiveness of nitrogen fixing rhizobia from mega-biodiversity ecosystem of Africa as 
well as monitoring the factors affecting the rhizobia, legume and symbiosis providing effective rhizobia is essential as it may result into the identification of supper inoculants for improving legume growth and yield and later providing economic benefit to legume producers. Therefore, more research and emphasis is required to popularize this cheap and eco-friendly technology for majority of smallholder farmers in Africa.

\section{Acknowledgements}

This study was funded by N2 Africa project and the Commission for Science and Technology (COSTECH) through a grant given to the Nelson Mandela African Institution of Science and Technology (NM-AIST).

\section{References}

[1] Howieson, J. and Committee, G.R.P. (2007) Technical Issues Relating to Agricultural Microbial Genetic Resources (AMiGRs), including Their Characteristics, Utilization, Preservation and Distribution: Draft Information Paper.

[2] Matiru, V.N. and Dakora, F.D. (2004) Potential Use of Rhizobial Bacteria as Promoters of Plant Growth for Increased Yield in Landraces of African Cereal Crops. African Journal of Biotechnology, 3, 1-7.

[3] Wolfe, D., Henderson, D., Hsiao, T. and Alvino, A. (1988) Interactive Water and Nitrogen Effects on Senescence of maize. II. Photosynthetic Decline and Longevity of Individual Leaves. Agronomy Journal, 80, 865-870. http://dx.doi.org/10.2134/agronj1988.00021962008000060005x

[4] Ougham, H.J., Morris, P. and Thomas, H. (2005) The Colors of Autumn Leaves as Symptoms of Cellular Recycling and Defenses against Environmental Stresses. Current Topics in Developmental Biology, 66, 135-160. http://dx.doi.org/10.1016/S0070-2153(05)66004-8

[5] Boddey, R.M., De Moraes Sá, J.C., Alves, B.J. and Urquiaga, S. (1997) The Contribution of Biological Nitrogen Fixation for Sustainable Agricultural Systems in the Tropics. Soil Biology and Biochemistry, 29, 787-799. http://dx.doi.org/10.1016/S0038-0717(96)00221-0

[6] McAllister, C.H., Beatty, P.H. and Good, A.G. (2012) Engineering Nitrogen Use Efficient Crop Plants: The Current Status. Plant Biotechnology Journal, 10, 1011-1025. http://dx.doi.org/10.1111/j.1467-7652.2012.00700.x

[7] Sanfo, S. and Gérard, F. (2012) Public Policies for Rural Poverty Alleviation: The Case of Agricultural Households in the Plateau Central Area of Burkina Faso. Agricultural Systems, 110, 1-9. http://dx.doi.org/10.1016/j.agsy.2012.02.006

[8] Niazi, T. (2004) Rural Poverty and the Green Revolution: The Lessons from Pakistan. Journal of Peasant Studies 31, 242-260. http://dx.doi.org/10.1080/0306615042000224294

[9] Mohammadi, K. and Sohrabi, Y. (2012) Bacterial Biofertilizers for Sustainable Crop Production: A Review. Journal of Agricultural and Biological Science, 7, 307-316.

[10] Eskin, N. (2012) Colonization of Zea mays by the Nitrogen Fixing Bacterium Gluconacetobacter diazotrophicus.

[11] Gothwal, R., Nigam, V., Mohan, M., Sasmal, D. and Ghosh, P. (2008) Screening of Nitrogen Fixers from Rhizospheric Bacterial Isolates Associated with Important Desert Plants. Applied Ecology and Environmental Research, 6, 101-109. http://dx.doi.org/10.15666/aeer/0602_101109

[12] Anwer, M.A. (2013) Characterization of Indigenous Soil Isolates of Aspergillus Niger Aggregate and Development of Their Commercial Formulations for the Management of Wilt Disease Complex of Chickpea and Tomato Caused by Fusarium spp. and Meloidogyne incognita. Thesis, Aligarh Muslim University, Aligarh.

[13] Chen, W., Yan, G. and Li, J. (1988) Numerical Taxonomic Study of Fast-Growing Soybean Rhizobia and a Proposal That Rhizobium fredii Be Assigned to Sinorhizobium gen. nov. International Journal of Systematic Bacteriology, 38, 392-397. http://dx.doi.org/10.1099/00207713-38-4-392

[14] Cooper, J., Wood, M. and Bjourson, A. (1985) Nodulation of Lotus pedunculatus in Acid Rooting Solution by Fastand Slow-Growing Rhizobia. Soil Biology and Biochemistry, 17, 487-492. http://dx.doi.org/10.1016/0038-0717(85)90015-X

[15] Jenkins, M.B., Virginia, R.A. and Jarrell, W.M. (1989) Ecology of Fast-Growing and Slow-Growing Mesquite-Nodulating Rhizobia in Chihuahuan and Sonoron Desert Ecosystems. Soil Science Society of America Journal, 53, 543-549. http://dx.doi.org/10.2136/sssaj1989.03615995005300020040x

[16] Deshwal, V., Singh, S., Kumar, P. and Chubey, A. (2013) Rhizobia Unique Plant Growth Promoting Rhizobacteria: A Review. International Journal of Life Sciences, 2, 74-86.

[17] Graham, P.H., Draeger, K.J., Ferrey, M.L., Conroy, M.J., Hammer, B.E., Martinez, E., Aarons, S.R. and Quinto, C. (1994) Acid pH Tolerance in Strains of Rhizobium and Bradyrhizobium, and Initial Studies on the Basis for Acid Tolerance of Rhizobium tropici UMR1899. Canadian Journal of Microbiology, 40, 198-207. http://dx.doi.org/10.1139/m94-033 
[18] Sprent, J.I. and James, E.K. (2007) Legume Evolution: Where Do Nodules and Mycorrhizas Fit in? Plant Physiology, 144, 575-581. http://dx.doi.org/10.1104/pp.107.096156

[19] Doyle, J.J. and Luckow, M.A. (2003) The Rest of the Iceberg. Legume Diversity and Evolution in a Phylogenetic Context. Plant Physiology, 131, 900-910. http://dx.doi.org/10.1104/pp.102.018150

[20] Forest, F. and Chase, M.W. (2009) Eurosid i. The TimeTree of Life. Oxford University Press, New York, 188-196.

[21] Tran, L.S.P. and Nguyen, H.T. (2009) Future Biotechnology of Legumes. In: Emerich, W.D. and Krishnan, H., Eds., Nitrogen Fixation in Crop Production, The American Society of Agronomy, Crop Science Society of America and Soil Science Society of America, Madison, 265-308.

[22] Wong, M. (2003) Ecological Restoration of Mine Degraded Soils, with Emphasis on Metal Contaminated Soils. Chemosphere, 50, 775-780. http://dx.doi.org/10.1016/S0045-6535(02)00232-1

[23] Freitas, H., Prasad, M. and Pratas, J. (2004) Plant Community Tolerant to Trace Elements Growing on the Degraded Soils of São Domingos Mine in the South East of Portugal: Environmental Implications. Environment International, 30, 65-72. http://dx.doi.org/10.1016/S0160-4120(03)00149-1

[24] Nhamo, N., Mupangwa, W., Siziba, S., Gatsi, T. and Chikazunga, D. (2003) The Role of Cowpea (Vigna unguiculata) and Other Grain Legumes in the Management of Soil Fertility in the Smallholder Farming Sector of Zimbabwe. In: Waddington, S.R., Ed., Grain Legumes and Green Manures for Soil Fertility in Southern Africa: Taking Stock of Progress, Soil Fert Net-CIMMYT, Harare, 119-127.

[25] Graham, P.H. and Vance, C.P. (2003) Legumes: Importance and Constraints to Greater Use. Plant Physiology, 131, 872-877. http://dx.doi.org/10.1104/pp.017004

[26] Ndakidemi, P.A., Bambara, S. and Makoi, J.H. (2011) Micronutrient Uptake in Common Bean (Phaseolus vulgaris L.) as Affected by Rhizobium Inoculation, and the Supply of Molybdenum and Lime. Plant Omics Journal, 4, 40-52.

[27] Stajković, O., Delić, D., Jošić, D., Kuzmanović, Đ., Rasulić, N. and Knežević-Vukčević, J. (2011) Improvement of Common Bean Growth by Co-Inoculation with Rhizobium and Plant Growth-Promoting Bacteria. Romanian Biotechnological Letters, 16, 5919-5926.

[28] Hendawey, M. and Younes, A. (2013) Biochemical Evaluation of Some Faba Bean Cultivars under Rainfed Conditions at El-Sheikh Zuwayid. Annals of Agricultural Sciences, 58, 183-193. http://dx.doi.org/10.1016/j.aoas.2013.07.010

[29] Dakora, F. and Keya, S. (1997) Contribution of Legume Nitrogen Fixation to Sustainable Agriculture in Sub-Saharan Africa. Soil Biology and Biochemistry, 29, 809-817. http://dx.doi.org/10.1016/S0038-0717(96)00225-8

[30] Wilkinson, H.H., Spoerke, J.M. and Parker, M.A. (1996) Divergence in Symbiotic Compatibility in a Legume-Bradyrhizobium Mutualism. Evolution, 50, 1470-1477. http://dx.doi.org/10.2307/2410884

[31] Marschner, P., Crowley, D. and Rengel, Z. (2011) Rhizosphere Interactions between Microorganisms and Plants Govern Iron and Phosphorus Acquisition along the Root Axis-Model and Research Methods. Soil Biology and Biochemistry, 43, 883-894. http://dx.doi.org/10.1016/j.soilbio.2011.01.005

[32] Kahindi, J.H.P., Woomer, P., George, T., de Souza Moreira, F.M., Karanja, N.K. and Giller, K.E. (1997) Agricultural Intensification, Soil Biodiversity and Ecosystem Function in the Tropics: The Role of Nitrogen-Fixing Bacteria. Applied Soil Ecology, 6, 55-76. http://dx.doi.org/10.1016/S0929-1393(96)00151-5

[33] Roychowdhury, R., Banerjee, U., Sofkova, S. and Tah, J. (2013) Organic Farming for Crop Improvement and Sustainable Agriculture in the Era of Climate Change. OnLine Journal of Biological Sciences, 13, 50-65. http://dx.doi.org/10.3844/ojbsci.2013.50.65

[34] Hardarson, G., Bliss, F.A., Cigales-Rivero, M., Henson, R.A., Kipe-Nolt, J.A., Longeri, L., Manrique, A., Pena-Cabriales, J., Pereira, P.A.A. and Sanabria, C. (1993) Genotypic Variation in Biological Nitrogen Fixation by Common Bean. Plant and Soil, 152, 59-70. http://dx.doi.org/10.1007/BF00016333

[35] Crews, T.E. (1999) The Presence of Nitrogen Fixing Legumes in Terrestrial Communities: Evolutionary vs. Ecological Considerations. Biogeochemistry, 46, 233-246. http://dx.doi.org/10.1007/BF01007581

[36] Parker, M.A., Malek, W. and Parker, I.M. (2006) Growth of an Invasive Legume Is Symbiont Limited in Newly Occupied Habitats. Diversity and Distributions, 12, 563-571. http://dx.doi.org/10.1111/j.1366-9516.2006.00255.x

[37] Ibel, M. (2009) Farmers Indigenous Practices for Conserving Important Tree Species in the Afigya Sekyere District of Ashanti. Master's Thesis, Kwame Nkrumah University of Science and Technology, Kumasi.

[38] Shechambo, F., Salehe, J. and Mariki, S. (2001) National Awareness Workshop on the Economic Value of Tanzania's Forest Ecosystems. GEF/UNDP/FAO Cross Border Biodiversity Project Reducing Biodiversity Loss at selected CrossBorder Sites in East Africa, Report of a Workshop Held on 15th August 2001 at the Courtyard Hotel, Dar es Salaam.

[39] Berrada, H., Nouioui, I., Houssaini, M.I., Gtari, M. and Benbrahim, K.F. (2012) Phenotypic and Genotypic Characterizations of Rhizobia Isolated from Root Nodules of Multiple Legume Species Native of Fez, Morocco. African Journal of Microbiology Research, 6, 5314-5324. 
[40] Berrada, H. and Fikri-Benbrahim, K. (2014) Taxonomy of the Rhizobia: Current Perspectives. British Microbiology Research Journal, 4, 616-639. http://dx.doi.org/10.9734/BMRJ/2014/5635

[41] Wolde-Meskel, E., Terefework, Z., Frostegård, Å. and Lindström, K. (2005) Genetic Diversity and Phylogeny of Rhizobia Isolated from Agroforestry Legume Species in Southern Ethiopia. International Journal of Systematic and Evolutionary Microbiology, 55, 1439-1452. http://dx.doi.org/10.1099/ijs.0.63534-0

[42] Rai, R., Dash, P.K., Mohapatra, T. and Singh, A. (2012) Phenotypic and Molecular Characterization of Indigenous Rhizobia Nodulating Chickpea in India. Indian Journal of Experimental Biology, 50, 340-350.

[43] Zahran, H.H., Abdel-Fattah, M., Yasser, M.M., Mahmoud, A.M. and Bedmar, E.J. (2012) Diversity and Environmental Stress Responses of Rhizobial Bacteria from Egyptian Grain Legumes. Australian Journal of Basic \& Applied Sciences, 6, 571-583.

[44] Al-Mujahidy, S.M.J., Hassan, M.M., Rahman, M.M. and Mamun-or-Rashid, A. (2013) Study on Measurement and Statistical Analysis of Adherent Soil Chemical Compositions of Leguminous Plants and Their Impact on Nitrogen Fixation. International Journal of Biosciences, 3, 112-119. http://dx.doi.org/10.12692/ijb/3.6.112-119

[45] Shahzad, F., Shafee, M., Abbas, F., Babar, S., Tariq, M. and Ahmad, Z. (2012) Isolation and Biochemical Characterization of Rhizobium meliloti from Root Nodules of Alfalfa (Medico sativa). The Journal of Animal and Plant Sciences, 22, 522-524.

[46] Mbaga, E.T. and Friesen, D. (2003) Adoptable Maize/Legume Systems for Improved Maize Production in Northern Tanzania. African Crop Science Conference Proceedings, 6, 649-654.

[47] Sprent, J.I. (2007) Evolving Ideas of Legume Evolution and Diversity: A Taxonomic Perspective on the Occurrence of Nodulation. New Phytologist, 174, 11-25. http://dx.doi.org/10.1111/j.1469-8137.2007.02015.x

[48] Gao, J.-L., Turner, S.L., Kan, F.L., Wang, E.T., Tan, Z.Y., Qiu, Y.H., Gu, J., Terefework, Z., Young, J.P.W. and Lindström, K. (2004) Mesorhizobium septentrionale sp. nov. and Mesorhizobium temperatum sp. nov., Isolated from Astragalus adsurgens Growing in the Northern Regions of China. International Journal of Systematic and Evolutionary Microbiology, 54, 2003-2012. http://dx.doi.org/10.1099/ijs.0.02840-0

[49] Hirsch, A.M., Lum, M.R. and Downie, J.A. (2001) What Makes the Rhizobia-Legume Symbiosis so Special? Plant Physiology, 127, 1484-1492. http://dx.doi.org/10.1104/pp.010866

[50] Becana, M. and Sprent, J.I. (1987) Nitrogen Fixation and Nitrate Reduction in the Root Nodules of Legumes. Physiologia Plantarum, 70, 757-765. http://dx.doi.org/10.1111/j.1399-3054.1987.tb04335.x

[51] Zahran, H.H. (1999) Rhizobium-Legume Symbiosis and Nitrogen Fixation under Severe Conditions and in an Arid Climate. Microbiology and Molecular Biology Reviews, 63, 968-989.

[52] Huber, D. and Watson, R. (1974) Nitrogen Form and Plant Disease. Annual Review of Phytopathology, 12, 139-165. http://dx.doi.org/10.1146/annurev.py.12.090174.001035

[53] Roosta, H.R. (2014) Effect of Ammonium: Nitrate Ratios in the Response of Strawberry to Alkalinity in Hydroponics. Journal of Plant Nutrition, 37, 1676-1689. http://dx.doi.org/10.1080/01904167.2014.888749

[54] Cao, W. and Tibbitts, T.W. (1993) Study of Various $\mathrm{NH}_{4}^{+} / \mathrm{NO}_{3}^{-}$Mixtures for Enhancing Growth of Potatoes. Journal of Plant Nutrition, 16, 1691-1704. http://dx.doi.org/10.1080/01904169309364643

[55] Chevalier, F., Rofidal, V., Vanova, P., Bergoin, A. and Rossignol, M. (2004) Proteomic Capacity of Recent Fluorescent Dyes for Protein Staining. Phytochemistry, 65, 1499-1506. http://dx.doi.org/10.1016/j.phytochem.2004.04.019

[56] Mastronunzio, J.E. and Benson, D.R. (2010) Wild Nodules Can Be Broken: Proteomics of Frankia in Field-Collected Root Nodules. Symbiosis, 50, 13-26. http://dx.doi.org/10.1007/s13199-009-0030-1

[57] Holtorf, H., Guitton, M.-C. and Reski, R. (2002) Plant Functional Genomics. Naturwissenschaften, 89, $235-249$. http://dx.doi.org/10.1007/s00114-002-0321-3

[58] D’Haeze, W. and Holsters, M. (2002) Nod Factor Structures, Responses, and Perception during Initiation of Nodule Development. Glycobiology, 12, 79R-105R. http://dx.doi.org/10.1093/glycob/12.6.79R

[59] Leidi, E.O. and Rodríguez-Navarro, D.N. (2000) Nitrogen and Phosphorus Availability Limit $\mathrm{N}_{2}$ Fixation in Bean. New Phytologist, 147, 337-346. http://dx.doi.org/10.1046/j.1469-8137.2000.00703.x

[60] Ndakidemi, P.A. and Dakora, F.D. (2003) Legume Seed Flavonoids and Nitrogenous Metabolites as Signals and Protectants in Early Seedling Development. Functional Plant Biology, 30, 729-745. http://dx.doi.org/10.1071/FP03042

[61] Banfalvi, Z. and Kondorosi, A. (1989) Production of Root Hair Deformation Factors by Rhizobium meliloti Nodulation Genes in Escherichia coli: HsnD (NodH) Is Involved in the Plant Host-Specific Modification of the NodABC Factor. Plant Molecular Biology, 13, 1-12. http://dx.doi.org/10.1007/BF00027330

[62] Gage, D.J., Bobo, T. and Long, S.R. (1996) Use of Green Fluorescent Protein to Visualize the Early Events of Symbiosis between Rhizobium meliloti and Alfalfa (Medicago sativa). Journal of Bacteriology, 178, 7159-7166. 
[63] Dudley, M.E., Jacobs, T.W. and Long, S.R. (1987) Microscopic Studies of Cell Divisions Induced in Alfalfa Roots by Rhizobium meliloti. Planta, 171, 289-301. http://dx.doi.org/10.1007/BF00398674

[64] Glick, B.R. (2003) Phytoremediation: Synergistic Use of Plants and Bacteria to Clean up the Environment. Biotechnology Advances, 21, 383-393. http://dx.doi.org/10.1016/S0734-9750(03)00055-7

[65] Haru, A. and Ethiopia, W. (2012) Influences of Inoculation Methods and Phosphorus Levels on Nitrogen Fixation Attributes and Yield of Soybean (Glycine max L.). American Journal of Plant Nutrition and Fertilization Technology, 2, 45-55. http://dx.doi.org/10.3923/ajpnft.2012.45.55

[66] Lechevalier, M.P. (1994) Taxonomy of the Genus Frankia (Actinomycetales). International Journal of Systematic Bacteriology, 44, 1-8. http://dx.doi.org/10.1099/00207713-44-1-1

[67] Abbasi, M.K., Manzoor, M. and Tahir, M.M. (2010) Efficiency of Rhizobium Inoculation and P Fertilization in Enhancing Nodulation, Seed Yield, and Phosphorus Use Efficiency by Field Grown Soybean under Hilly Region of Rawalakot Azad Jammu and Kashmir, Pakistan. Journal of Plant Nutrition, 33, 1080-1102. http://dx.doi.org/10.1080/01904161003729782

[68] Györgypal, Z., Iyer, N. and Kondorosi, A. (1988) Three Regulatory nodD Alleles of Diverged Flavonoid-Specificity Are Involved in Host-Dependent Nodulation by Rhizobium meliloti. Molecular and General Genetics MGG, 212, 8592. http://dx.doi.org/10.1007/BF00322448

[69] Streeter, J.G. (1994) Failure of Inoculant Rhizobia to Overcome the Dominance of Indigenous Strains for Nodule Formation. Canadian Journal of Microbiology, 40, 513-522. http://dx.doi.org/10.1139/m94-084

[70] Slattery, J., Pearce, D. and Slattery, W. (2004) Effects of Resident Rhizobial Communities and Soil Type on the Effective Nodulation of Pulse Legumes. Soil Biology and Biochemistry, 36, 1339-1346. http://dx.doi.org/10.1016/j.soilbio.2004.04.015

[71] Sironval, C., Bonnier, C. and Verlinden, J.P. (1957) Action of Day-Length on Nodule Formation and Chlorophyll Content in Soybean. Physiologia Plantarum, 10, 697-707. http://dx.doi.org/10.1111/j.1399-3054.1957.tb06976.x

[72] Gwata, E., Wofford, D.S., Boote, K. and Mushoriwa, H. (2004) Determination of Effective Nodulation in Early Juvenile Soybean Plants for Genetic and Biotechnology Studies. African Journal of Biotechnology, 2, 417-420.

[73] Spaink, H.P. (2000) Root Nodulation and Infection Factors Produced by Rhizobial Bacteria. Annual Reviews in Microbiology, 54, 257-288. http://dx.doi.org/10.1146/annurev.micro.54.1.257

[74] Schultze, M. and Kondorosi, A. (1998) Regulation of Symbiotic Root Nodule Development. Annual Review of Genetics, 32, 33-57. http://dx.doi.org/10.1146/annurev.genet.32.1.33

[75] Simms, E.L. and Taylor, D.L. (2002) Partner Choice in Nitrogen-Fixation Mutualisms of Legumes and Rhizobia. Integrative and Comparative Biology, 42, 369-380. http://dx.doi.org/10.1093/icb/42.2.369

[76] Rice-Evans, C. (2001) Flavonoid Antioxidants. Current Medicinal Chemistry, 8, 797-807. http://dx.doi.org/10.2174/0929867013373011

[77] Broughton, W.J., Zhang, F., Perret, X. and Staehelin, C. (2003) Signals Exchanged between Legumes and Rhizobium: Agricultural Uses and Perspectives. Plant and Soil, 252, 129-137. http://dx.doi.org/10.1023/A:1024179717780

[78] Ardourel, M., Demont, N., Debelle, F., Maillet, F., de Billy, F., Promé, J.-C., Dénarié, J. and Truchet, G. (1994) Rhizobium meliloti Lipooligosaccharide Nodulation Factors: Different Structural Requirements for Bacterial Entry into Target Root Hair Cells and Induction of Plant Symbiotic Developmental Responses. The Plant Cell Online, 6, 1357-1374. http://dx.doi.org/10.1105/tpc.6.10.1357

[79] Botha, W.J., Jaftha, J.B., Bloem, J.F., Habig, J.H. and Law, I.J. (2004) Effect of Soil Bradyrhizobia on the Success of Soybean Inoculant Strain CB 1809. Microbiological Research, 159, 219-231. http://dx.doi.org/10.1016/j.micres.2004.04.004

[80] Ampomah, O.Y., Ofori-Ayeh, E., Solheim, B. and Svenning, M.M. (2008) Host Range, Symbiotic Effectiveness and Nodulation Competitiveness of Some Indigenous Cowpea Bradyrhizobia Isolates from the Transitional Savanna Zone of Ghana. African Journal of Biotechnology, 7, 988-996.

[81] Doku, E. (1969) Host Specificity among Five Species in the Cowpea Cross-Inoculation Group. Plant and Soil, 30, 126128. http://dx.doi.org/10.1007/BF01885271

[82] Subba-Rao, N., Mateos, P.F., Baker, D., Pankratz, H.S., Palma, J., Dazzo, F.B. and Sprent, J.I. (1995) The Unique RootNodule Symbiosis between Rhizobium and the Aquatic Legume, Neptunia natans (L. f.) Druce. Planta, 196, 311-320. http://dx.doi.org/10.1007/BF00201390

[83] Bala, A. and Giller, K.E. (2006) Relationships between Rhizobial Diversity and Host Legume Nodulation and Nitrogen Fixation in Tropical Ecosystems. Nutrient Cycling in Agroecosystems, 76, 319-330. http://dx.doi.org/10.1007/s10705-005-2003-y

[84] Gao, W. and Yang, S. (1995) A Rhizobium Strain That Nodulates and Fixes Nitrogen in Association with Alfalfa and Soy- 
bean Plants. Microbiology, 141, 1957-1962. http://dx.doi.org/10.1099/13500872-141-8-1957

[85] Ågren, G.I. (1985) Theory for Growth of Plants Derived from the Nitrogen Productivity Concept. Physiologia Plantarum, 64, 17-28. http://dx.doi.org/10.1111/j.1399-3054.1985.tb01207.x

[86] Kumar Gothwal, R., Kumar Nigam, V., Mohan, M.K., Sasmal, D. and Ghosh, P. (2007) Extraction of Bulk DNA from Thar Desert Soils for Optimization of PCR-DGGE Based Microbial Community Analysis. Electronic Journal of Biotechnology, 10, 400-408. http://dx.doi.org/10.2225/vol10-issue3-fulltext-6

[87] Ghimire, A. (2002) A Review on Organic Farming for Sustainable Agriculture. Department of Agriculture Extension and Rural Sociology Institute of Agriculture and Animal Science Rampur, Chitwan, 6.

[88] Botha, W.J., Jaftha, J.B., Bloem, J.F., Habig, J.H. and Law, I.J. (2004) Effect of Soil Bradyrhizobia on the Success of Soybean Inoculant Strain CB 1809. Microbiological Research, 159, 219-231. http://dx.doi.org/10.1016/j.micres.2004.04.004

[89] Immanuel, R.R., Imayavaramban, V., Elizabeth, L.L., Kannan, T. and Murugan, G. (2010) Traditional Farming Knowledge on Agroecosystem Conservation in Northeast Coastal Tamil Nadu. Indian Journal of Traditional Knowledge, 9, 366-374.

[90] Reghuvaran, A., Jacob, K.K. and Ravindranath, A.D. (2014) Isolation and Characterization of Nitrogen Fixing Bacteria from Raw Coir Pith. African Journal of Biotechnology, 11, 7063-7071.

[91] Lodewyckx, C., Vangronsveld, J., Porteous, F., Moore, E.R., Taghavi, S., Mezgeay, M. and der Lelie, D.V. (2002) Endophytic Bacteria and Their Potential Applications. Critical Reviews in Plant Sciences, 21, 583-606. http://dx.doi.org/10.1080/0735-260291044377

[92] Rakash, N. and Rana, K. (2013) Food Legumes for Livelihood and Nutritional Security in North Eastern Himalayan Region: Prospects and Constraints. Indian Journal of Agricultural Sciences, 83, 899-906.

[93] Davidson, E.A. (2009) The Contribution of Manure and Fertilizer Nitrogen to Atmospheric Nitrous Oxide since 1860. Nature Geoscience, 2, 659-662. http://dx.doi.org/10.1038/ngeo608

[94] Carpenter, S.R., Caraco, N.F., Correll, D.L., Howarth, R.W., Sharpley, A.N. and Smith, V.H. (1998) Nonpoint Pollution of Surface Waters with Phosphorus and Nitrogen. Ecological Applications, 8, 559-568. http://dx.doi.org/10.1890/1051-0761(1998)008[0559:NPOSWW]2.0.CO;2

[95] Sadowsky, M.J., Cregan, P.B. and Keyser, H.H. (1988) Nodulation and Nitrogen Fixation Efficacy of Rhizobium fredii with Phaseolus vulgaris Genotypes. Applied and Environmental Microbiology, 54, 1907-1910.

[96] Mpepereki, S., Wollum II, A. and Makonese, F. (1996) Diversity in Symbiotic Specificity of Cowpea Rhizobia Indigenous to Zimbabwean Soils. Plant and Soil, 186, 167-171. http://dx.doi.org/10.1007/BF00035071

[97] Balasubramanian, V. and Sinha, S. (1976) Effects of Salt Stress on Growth, Nodulation and Nitrogen Fixation in Cowpea and Mung Beans. Physiologia Plantarum, 36, 197-200. http://dx.doi.org/10.1111/j.1399-3054.1976.tb03935.x

[98] Elsheikh, E. and Wood, M. (1990) Salt Effects on Survival and Multiplication of Chickpea and Soybean Rhizobia. Soil Biology and Biochemistry, 22, 343-347. http://dx.doi.org/10.1016/0038-0717(90)90111-C

[99] LaRue, T.A. and Patterson, T.G. (1981) How Much Nitrogen Do Legumes Fix? Advances in Agronomy, 34, 15-38. http://dx.doi.org/10.1016/S0065-2113(08)60883-4

[100] Graham, P.H. (1992) Stress Tolerance in Rhizobium and Bradyrhizobium, and Nodulation under Adverse Soil Conditions. Canadian Journal of Microbiology, 38, 475-484. http://dx.doi.org/10.1139/m92-079

[101] Hungria, M. and Vargas, M.A. (2000) Environmental Factors Affecting $N_{2}$ Fixation in Grain Legumes in the Tropics, with an Emphasis on Brazil. Field Crops Research, 65, 151-164. http://dx.doi.org/10.1016/S0378-4290(99)00084-2

[102] Figueiredo, M.V., Burity, H.A., Martínez, C.R. and Chanway, C.P. (2008) Alleviation of Drought Stress in the Common Bean (Phaseolus vulgaris L.) by Co-Inoculation with Paenibacillus polymyxa and Rhizobium tropici. Applied Soil Ecology, 40, 182-188. http://dx.doi.org/10.1016/j.apsoil.2008.04.005

[103] Alexandre, A. and Oliveira, S. (2013) Response to Temperature Stress in Rhizobia. Critical Reviews in Microbiology, 39, 219-228. http://dx.doi.org/10.3109/1040841X.2012.702097

[104] Zahran, H.H. (2001) Rhizobia from Wild Legumes: Diversity, Taxonomy, Ecology, Nitrogen Fixation and Biotechnology. Journal of Biotechnology, 91, 143-153. http://dx.doi.org/10.1016/S0168-1656(01)00342-X

[105] Naeem, F., Malik, K.A. and Hafeez, F.Y. (2008) Pisum sativum-Rhizobium Interactions under Different Environmental Stresses. Pakistan Journal of Botany, 40, 2601-2612.

[106] Michiels, J., Verreth, C. and Vanderleyden, J. (1994) Effects of Temperature Stress on Bean-Nodulating Rhizobium Strains. Applied and Environmental Microbiology, 60, 1206-1212.

[107] Ledgard, S. and Steele, K. (1992) Biological Nitrogen Fixation in Mixed Legume/Grass Pastures. Plant and Soil, 141, 137-153. http://dx.doi.org/10.1007/BF00011314 
[108] Eaglesham, A.R.J. and Ayanaba, A. (1984) Tropical Stress Ecology of Rhizobia, Root Nodulation and Legume Fixation. In: Subba Rao, N.S., Ed., Current Developments in Biological Nitrogen Fixation, Edward Arnold Ltd., London, 1-35.

[109] Francis, A.J. (1982) Effects of Acidic Precipitation and Acidity on Soil Microbial Processes. Springer, Berlin.

[110] Bordeleau, L. and Prévost, D. (1994) Nodulation and Nitrogen Fixation in Extreme Environments. In: Graham, P.H., Sadowsky, M.J. and Vance, C.P., Eds., Symbiotic Nitrogen Fixation, Springer, Dordrecht, 115-125. http://dx.doi.org/10.1007/978-94-011-1088-4_13

[111] Andrew, C. (1978) Legumes and Acid Soils. In: Döbereiner, J., Burris, R.H., Hollaender, A., Franco, A.A., Neyra, C.A. and Scott, D.B., Eds., Limitations and Potentials for Biological Nitrogen Fixation in the Tropics, Springer, New York, 135-160. http://dx.doi.org/10.1007/978-1-4615-8957-0_11

[112] Kellman, A.W. (2008) Rhizobium Inoculation, Cultivar and Management Effects on the Growth, Development and Yield of Common Bean (Phaseolus vulgaris L.). Lincoln University, San Francisco.

[113] National Soil Services (1990) Classification for General Soil Fertility Evaluation. NSS, Mlingano Research Institute, Tanga, $48 \mathrm{p}$.

[114] Solomon, D. and Lehman, N. (2000) Loss of Phosphorus from Soil in Semi-Arid Northern Tanzania as a Result of Cropping: Evidence from sequential Extraction and 31P-NMR Spectroscopy. European Journal of Soil Science, 51, 699-708. http://dx.doi.org/10.1111/j.1365-2389.2000.00326.x

[115] Federal Ministry of Agriculture and Natural Resources (1990) Literature Review on Soil Fertility Investigations in Nigeria. FMANR, Lagos, 281 p.

[116] Schwartz, H.F. and Corrales, M.A.P. (1989) Nutritional Disorders in Beans. In: Schwartz, H.F. and Corrales, M.A.P., Eds., Bean Production Problems in the Tropics, 2nd Edition, International Center for Tropical Agriculture (CIAT), Cali, 57-604.

[117] Marx, E.S., Hart, J. and Stevens, R.G. (1996) Soil Test Interpretation Guide. Oregon State University Extension Services. Oregon State University, Corvallis, $7 \mathrm{p}$.

[118] Bouhmouch, I., Souad-Mouhsine, B., Brhada, F. and Aurag, J. (2005) Influence of Host Cultivars and Rhizobium species on the Growth and Symbiotic Performance of Phaseolus vulgaris under Salt Stress. Journal of Plant Physiology, 162, 1103-1113. http://dx.doi.org/10.1016/j.jplph.2004.12.003

[119] Singleton, P., El Swaify, S. and Bohlool, B. (1982) Effect of Salinity on Rhizobium Growth and Survival. Applied and Environmental Microbiology, 44, 884-890.

[120] Bernstein, L., Francois, L. and Clark, R. (1974) Interactive Effects of Salinity and Fertility on Yields of Grains and Vegetables. Agronomy Journal, 66, 412-421. http://dx.doi.org/10.2134/agronj1974.00021962006600030023x

[121] Maas, E.V. and Hoffman, G.J. (1977) Crop Salt Tolerance-Current Assessment. Journal of the Irrigation and Drainage Division, 103, 115-134.

[122] Sulieman, S. and Tran, L.S.P. (2013) Asparagine: An Amide of Particular Distinction in the Regulation of Symbiotic Nitrogen Fixation of Legumes. Critical Reviews in Biotechnology, 33, 309-327. http://dx.doi.org/10.3109/07388551.2012.695770

[123] Ballen, K.G. and Graham, P.H. (2002) The Role of Acid pH in Symbiosis between Plants and Soil Organisms. In: Rengel, Z., Ed., Handbook of Plant Growth pH as the Master Variable, Marcel Dekker, New York, 383-404. http://dx.doi.org/10.1201/9780203910344.ch15

[124] Qureshi, M.I., Muneer, S., Bashir, H., Ahmad, J. and Iqbal, M. (2010) Nodule Physiology and Proteomics of Stressed Legumes. Advances in Botanical Research, 56, 1-48. http://dx.doi.org/10.1016/B978-0-12-381518-7.00001-7

[125] Saxena, A. and Rewari, R. (1992) Differential Responses of Chickpea (Cicer arietinum L.) Rhizobium Combinations to Saline Soil Conditions. Biology and Fertility of Soils, 13, 31-34. http://dx.doi.org/10.1007/BF00337234

[126] Chatel, D. and Parker, C. (1973) Survival of Field-Grown Rhizobia over the Dry Summer Period in Western Australia. Soil Biology and Biochemistry, 5, 415-423. http://dx.doi.org/10.1016/0038-0717(73)90068-0

[127] Hafeez, F.Y., Aslam, Z. and Malik, K.A. (1988) Effect of Salinity and Inoculation on Growth, Nitrogen Fixation and Nutrient Uptake of Vigna radiata (L.) Wilczek. Plant and Soil, 106, 3-8. http://dx.doi.org/10.1007/BF02371188

[128] Hartel, P.G. and Alexander, M. (1984) Temperature and Desiccation Tolerance of Cowpea Rhizobia. Canadian Journal of Microbiology, 30, 820-823. http://dx.doi.org/10.1139/m84-125

[129] Mnasri, B., Tajini, F., Trabelsi, M., Aouani, M.E. and Mhamdi, R. (2007) Rhizobium gallicum as an Efficient Symbiont for Bean Cultivation. Agronomy for Sustainable Development, 27, 331-336. http://dx.doi.org/10.1051/agro:2007024

[130] Rodriguez-Navarro, D.N., Buendia, A.M., Camacho, M., Lucas, M.M. and Santamaria, C. (2000) Characterization of Rhizobium spp. Bean Isolates from South-West Spain. Soil Biology and Biochemistry, 32, 1601-1613. 
http://dx.doi.org/10.1016/S0038-0717(00)00074-2

[131] Andrade, D., Murphy, P.J. and Giller, K.E. (2002) The Diversity of Phaseolus-Nodulating Rhizobial Populations Is Altered by Liming of Acid Soils Planted with Phaseolus vulgaris L. in Brazil. Applied and Environmental Microbiology, 68, 4025-4034. http://dx.doi.org/10.1128/AEM.68.8.4025-4034.2002

[132] Aliyu, I., Yusuf, A. and Abaidoo, R. (2013) Response of Grain Legumes to Rhizobial Inoculation in Two Savanna Soils of Nigeria. African Journal of Microbiology Research, 7, 1332-1342.

[133] Mwendaa, G., Karanjac, N., Bogaa, H., Kahindib, J., Muigaia, A. and Odeed, D. (2011) Abundance and Diversity of Legume Nodulating Rhizobia in Soils of Embu District, Kenya. Tropical and Subtropical Agroecosystems, 13, 1-10.

[134] Mathu, S., Herrmann, L., Pypers, P., Matiru, V., Mwirichia, R. and Lesueur, D. (2012) Potential of Indigenous Bradyrhizobia versus Commercial Inoculants to Improve Cowpea (Vigna unguiculata L. Walp.) and Green Gram (Vigna radiata L. Wilczek.) Yields in Kenya. Soil Science and Plant Nutrition, 58, 750-763. http://dx.doi.org/10.1080/00380768.2012.741041

[135] Martyniuk, S. and Jadwiga, O. (2008) Populations of Rhizobia in Some Polish Soils Not Planted with Legumes. Ekologija, 54, 165-168. http://dx.doi.org/10.2478/V10055-008-0025-X

[136] Soe, K.M. and Yamakawa, T. (2013) Low-Density Co-Inoculation of Myanmar Bradyrhizobium yuanmingense MAS34 and Streptomyces griseoflavus P4 to Enhance Symbiosis and Seed Yield in Soybean Varieties. American Journal of Plant Sciences, 4, 1879-1892. http://dx.doi.org/10.4236/ajps.2013.49231

[137] Nutman, P. and Hearne, R. (1980) Persistence of Nodule Bacteria in Soil under Long-Term Cereal Cultivation. Rothamsted Experimental Station Report for 1979, Part 2, 77-90.

[138] Dudeja, S. and Khurana, A. (1989) Persistence of Bradyrhizobium sp. (Cajanus) in a Sandy Loam. Soil Biology and Biochemistry, 21, 709-713. http://dx.doi.org/10.1016/0038-0717(89)90068-0

[139] Dennis, A. and Gichuki, N. (2012) Effects of Legume-Based Rotational Cropping on Rhizobia Assemblage in an Irrigated Rangeland in Southern Kenya. The International Journal of Environmental Sustainability, 8, 95-105.

[140] Maingi, J.M. (2011) Nitrogen Fixation in Promisccuous Soybean (Glycine max (1.) Merril) Varieties in Eastern Kenya. Journal of Tropical Microbiology and Biotechnology, 6, 169 p. http://ir-library.ku.ac.ke/handle/123456789/793

[141] Adler, K. (2008) Exploring the Implications of Introducing Inoculated Legumes in Southern Ethiopia: A Systemic Analysis of the Factors Affecting Farmer Adoption and Nitrogen Synchrony. Master's Thesis, Norwegian University of Life Sciences, Ås.

[142] Graham, P. (1976) Identification and Classification of Root Nodule Bacteria. Symbiotic Nitrogen Fixation in Plants, 7, 99.

[143] Sadowsky, M.J. (1983) Physiological, Serological, and Plasmid Characterization of Fast-Growing Rhizobia That Nodulate Soybeans. Master's Thesis, University of Hawaii, Honolulu, 40.

[144] Kapoor, K.K. and Dudeja, S.S. (1995) Ecology of Legume Root Nodule Bacteria. In: Mishra, P.C., Behera, N., Senapati, B.K. and Guru, B.C., Eds., Advances in Ecology and Environmental Sciences, Ashish Publishing House, New Delhi, 17-33.

[145] Read, M.P. (1953) The Establishment of Serologically Identifiable Strains of Rhizobium trifolii in Field Soils in Competition with the Native Microflora. Journal of General Microbiology, 9, 1-14. http://dx.doi.org/10.1099/00221287-9-1-1

[146] Kleczkowski, A. and Thornton, H.G. (1944) A Serological Study of Root Nodule Bacteria from Pea and Clover Inoculation Groups. Journal of Bacteriology, 48, 661-672.

[147] Beynon, J. and Josey, D. (1980) Demonstration of Heterogeneity in a Natural Population of Rhizobium phaseoli Using Variation in Intrinsic Antibiotic Resistance. Journal of General Microbiology, 118, 437-442.

[148] Ahmad, M.H., Eaglesham, A.R.J. and Hassouna, S. (1981) Examining Serological Diversity of “Cowpea” Rhizobia by the ELISA Technique. Archives of Microbiology, 130, 281-287. http://dx.doi.org/10.1007/BF00425941

[149] Koontz, F.P. and Faber, J.E. (1961) Somatic Antigens of Rhizobium japonicum. Soil Science, 91, $228-232$. http://dx.doi.org/10.1097/00010694-196104000-00002

[150] Raposeiras, R., Marriel, I.E., Muzzi, M.R.S., Paiva, E., Pereira Filho, I.A., Carvalhais, L.C. and Sá, N.M.H.D. (2006) Rhizobium Strains Competitiveness on Bean Nodulation in Cerrado Soils. Pesquisa Agropecuária Brasileira, 41, 439447. http://dx.doi.org/10.1590/S0100-204X2006000300010

[151] Bizarro, M.J., Giongo, A., Vargas, L.K., Roesch, L.F.W., Gano, K.A., De Sá, E.L.S. and Selbach, P.A. (2011) Genetic Variability of Soybean Bradyrhizobia Populations under Different Soil Managements. Biology and Fertility of Soils, 47, 357-362. http://dx.doi.org/10.1007/s00374-010-0512-6

[152] Amarger, N. (2001) Rhizobia in the Field. Advances in Agronomy, 73, 109-168. http://dx.doi.org/10.1016/S0065-2113(01)73006-4 
[153] Dudman, W. (1971) Antigenic Analysis of Rhizobium japonicum by Immunodiffusion. Applied Microbiology, 21, 973985.

[154] Crozat, Y., Cleyet-Marel, J.C. and Corman, A. (1987) Use of the Fluorescent Antibody Technique to Characterize Equilibrium Survival Concentrations of Bradyrhizobium japonicum Strains in Soil. Biology and Fertility of Soils, 4, 85-90.

[155] Assmus, B., Schloter, M., Kirchhof, G., Hutzler, P. and Hartmann, A. (1997) Improved in Situ Tracking of Rhizosphere Bacteria Using Dual Staining with Fluorescence-Labeled Antibodies and rRNA-Targeted Oligonucleotides. Microbial Ecology, 33, 32-40. http://dx.doi.org/10.1007/s002489900005

[156] Moawad, H., Abd El-Rahim, W.M. and Abd El-Haleem, D. (2004) Performance of Phaseolus Bean Rhizobia in Soils from the Major Production Sites in the Nile Delta. Comptes Rendus Biologies, 327, 445-453. http://dx.doi.org/10.1016/j.crvi.2004.03.005

[157] Venieraki, A., Dimou, M., Vezyri, E., Kefalogianni, I., Argyris, N., Liara, G., Pergalis, P., Chatzipavlidis, I. and Katinakis, P. (2011) Characterization of Nitrogen-Fixing Bacteria Isolated from Field-Grown Barley, Oat, and Wheat. The Journal of Microbiology, 49, 525-534. http://dx.doi.org/10.1007/s12275-011-0457-y

[158] Kumar Gothwal, R., Kumar Nigam, V., Mohan, M.K., Sasmal, D. and Ghosh, P. (2007) Extraction of Bulk DNA from Thar Desert Soils for Optimization of PCR-DGGE Based Microbial Community Analysis. Electronic Journal of Biotechnology, 10, 400-408. http://dx.doi.org/10.1007/s12275-011-0457-y

[159] Otieno, P., Muthomi, J., Cheminingwa, G. and Nderitu, J. (2009) Effect of Rhizobia Inoculation, Farm Yard Manure and Nitrogen Fertilizer on Nodulation and Yield of Food Grain Legumes. Journal of Biological Sciences, 9, 326-332. http://dx.doi.org/10.3923/jbs.2009.326.332

[160] Moawad, H., Abd el-Rahim, W.M., Abd el-Aleem, D. and Abo Sedera, S.A. (2005) Persistence of Two Rhizobium etli Inoculant Strains in Clay and Silty Loam Soils. Journal of Basic Microbiology, 45, 438-446. http://dx.doi.org/10.1002/jobm.200510590

[161] Mehrpouyan, M. (2011) Nitrogen Fixation Efficiency in Native Strains Compared with Non-Native Strains of Rhizobium leguminosarum. Proceedings of the 2011 International Conference on Environment Science and Engineering, Bali Island, 1-3 April 2011, 216-219.

[162] Gicharu, G., Gitonga, N., Boga, H., Cheruiyot, R. and Maingi, J. (2013) Effect of Inoculating Selected Climbing Bean Cultivars with Different Rhizobia Strains on Nitrogen Fixation. Online International Journal of Microbiology Research, 1, 25-31.

[163] Kremer, R.J. and Peterson, H.L. (1982) Nodulation Efficiency of Legume Inoculation as Determined by Intrinsic Antibiotic Resistance. Applied and Environmental Microbiology, 43, 636-642.

[164] Muthini, M., Maingi, J.M., Muoma, J.O., Amoding, A., Mukaminega, D., Osoro, N., Mgutu, A. and Ombori, O. (2014) Morphological Assessment and Effectiveness of Indigenous Rhizobia Isolates that Nodulate P. vulgaris in Water Hyacinth Compost Testing Field in Lake Victoria Basin. British Journal of Applied Science \& Technology, 4, 718-738.

[165] Oliveira-Longatti, S., Marra, L.M. and Moreira, F. (2013) Evaluation of Plant Growth-Promoting Traits of Burkholderia and Rhizobium Strains Isolated from Amazon Soils for Their Co-Inoculation in Common Bean. African Journal of Microbiology Research, 7, 948-959. http://dx.doi.org/10.5897/AJMR12.1055

[166] Weaver, R. and Frederick, L. (1974) Effect of Inoculum Rate on Competitive Nodulation of Glycine max L. Merrill. II. Field Studies. Agronomy Journal, 66, 233-236. http://dx.doi.org/10.2134/agronj1974.00021962006600020015x

[167] Singleton, P., El Swaify, S. and Bohlool, B. (1982) Effect of Salinity on Rhizobium Growth and Survival. Applied and Environmental Microbiology, 44, 884-890.

[168] Abaidoo, R.C. and van Kessel, C. (1989) ${ }^{15} \mathrm{~N}$-Uptake, $\mathrm{N}_{2}$-Fixation and Rhizobial Interstrain Competition in Soybean and Bean, Intercropped with Maize. Soil Biology and Biochemistry, 21, 155-159. http://dx.doi.org/10.1016/0038-0717(89)90025-4

[169] Allen, J.R. and Obura, R.K. (1983) Yield of Corn, Cowpea, and Soybean under Different Intercropping Systems. Agronomy Journal, 75, 1005-1009. http://dx.doi.org/10.2134/agronj1983.00021962007500060032x

[170] Gibson, A. and Elkan, G. (1987) Evaluation of Nitrogen Fixation by Legumes in the Greenhouse and Growth Chamber. In: HElkan, G., Ed., Symbiotic Nitrogen Fixation Technology, Marcel Dekker, New York, 321-369.

[171] Martin, I., Tenorio, J.L. and Ayerbe, L. (1994) Yield, Growth, and Water Use of Conventional and Semi-Leafless Peas in Semiarid Environments. Crop Science, 34, 1576-1583. http://dx.doi.org/10.2135/cropsci1994.0011183X003400060029x

[172] Ball, R.A., Purcell, L.C. and Vories, E.D. (2000) Short-Season Soybean Yield Compensation in Response to Population and Water Regime. Crop Science, 40, 1070-1078. http://dx.doi.org/10.2135/cropsci2000.4041070x

[173] Denton, M.D., Coventry, D.R., Bellotti, W.D. and Howieson, J.G. (2000) Distribution, Abundance and Symbiotic Effectiveness of Rhizobium leguminosarum bv. trifolii from Alkaline Pasture Soils in South Australia. Animal Production 
Science, 40, 25-35. http://dx.doi.org/10.1071/EA99035

[174] Sharma, S.R., Rao, N.K., Gokhale, T.S. and Ismail, S. (2012) Isolation and Characterization of Salt-Tolerant Rhizobia Native to the Desert Soils of United Arab Emirates. Emirates Journal of Food and Agriculture, 25, 102-108. http://dx.doi.org/10.9755/ejfa.v25i2.7590 
Scientific Research Publishing (SCIRP) is one of the largest Open Access journal publishers. It is currently publishing more than 200 open access, online, peer-reviewed journals covering a wide range of academic disciplines. SCIRP serves the worldwide academic communities and contributes to the progress and application of science with its publication.

Other selected journals from SCIRP are listed as below. Submit your manuscript to us via either submit@scirp.org or Online Submission Portal.
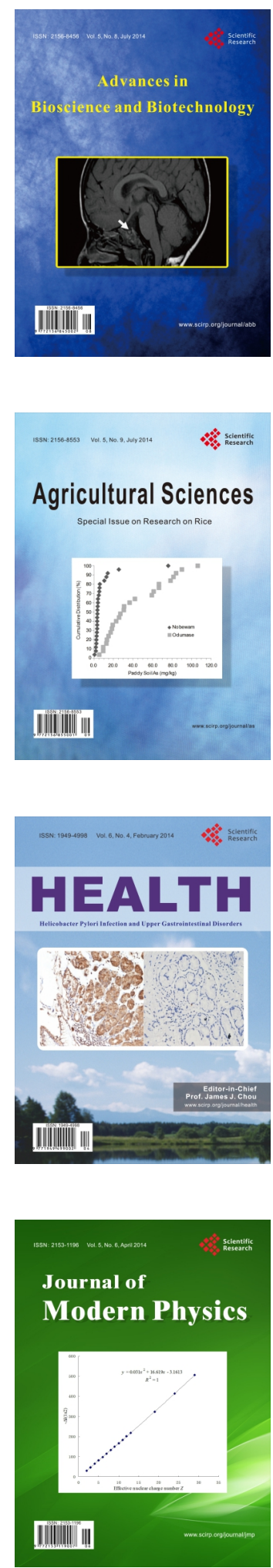
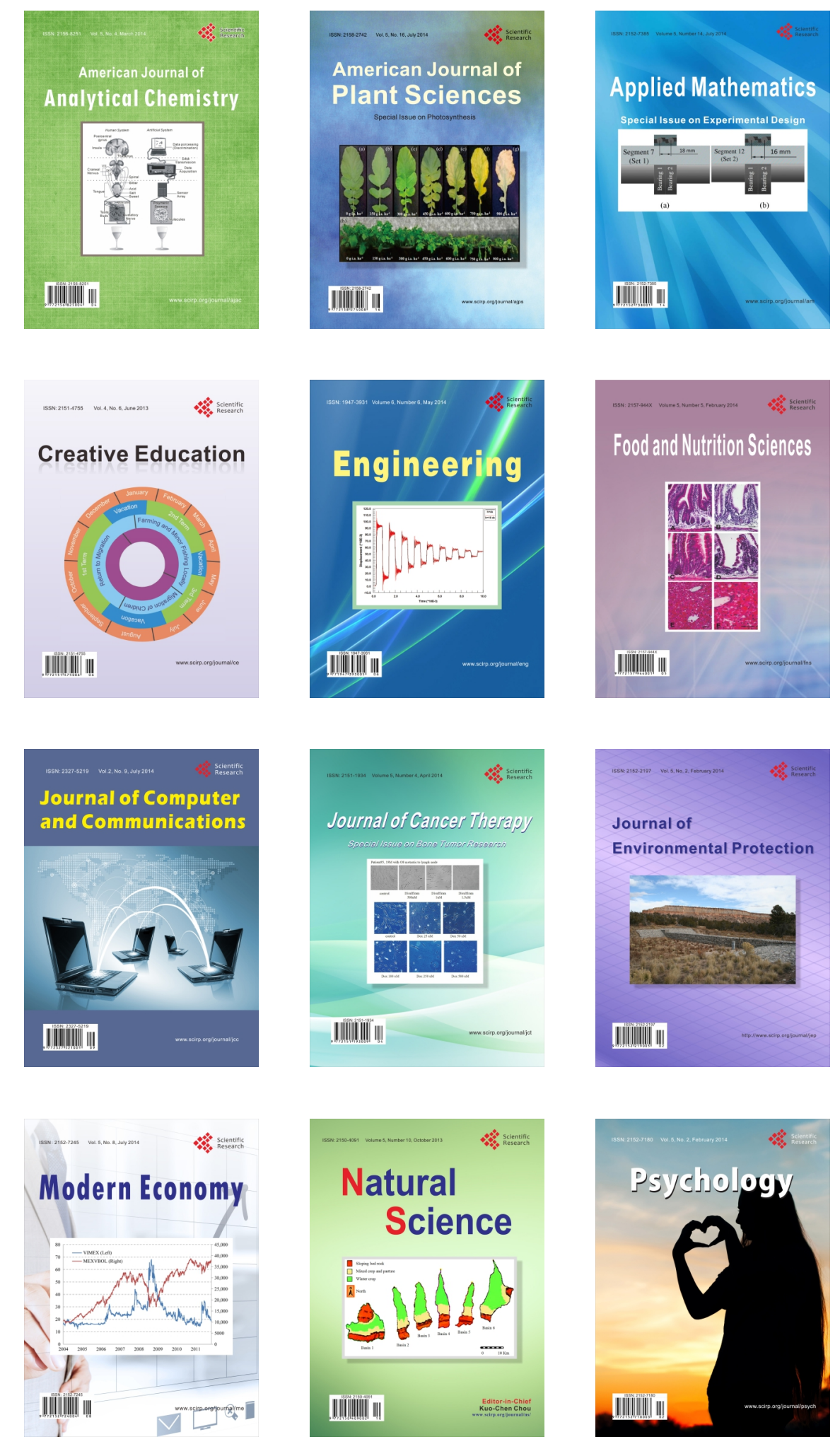